\title{
COMMENTS
}

\section{Neutrality As Political Opinion: A New Asylum Standard for a Post-Elias-Zacarias World}

\author{
Mark G. Artlip $\dagger$
}

Just as antimatter is an expression of matter, and atheism is arguably a form of religious belief, many courts and commentators have philosophized that neutrality constitutes a form of political opinion. This philosophical question becomes a real-life controversy when an alien seeks asylum in the United States under the Refugee Aict of 1980 ("Refugee Act") ${ }^{1}$ by claiming a fear of persecution on account of his neutrality rather than because of a traditional political stance.

Consider, for example, Joe Victim, a peasant in the tiny republic of San Marcos. One evening, guerrillas from the San Marcos People's Front visit Joe at his home and "invite" him to join their war against the oppressive military government. Facing an offer he should not refuse, Joe nonetheless resists the recruitment, voicing his desire to remain neutral in the ongoing conflict. The guerrillas threaten Joe and leave, at which point Joe packs his bags and leaves-for the United States. Upon being caught entering the United States illegally, Joe applies for po-

† B.B.A. 1991, Texas A\&M University; J.D. Candidate 1994, The University of Chicago.

1 Pub L No 96-212, 94 Stat 102 (1980), codified at 8 USC $\S \S 1101$ et seq (1988 \& Supp 1992). Under the Refugee Act, an alien may petition for asylum in the United States, 8 USC $\$ 1158$, if he can demonstrate a well-founded fear of persecution on account of race, religion, political opinion, or social group membership in his homeland. See 8 USC $\S 1101(\mathrm{a})(42)(\mathrm{A})$. 
litical asylum. His application raises two questions: Is Joe's neutrality a form of protected political opinion, and was he persecuted on account of this opinion?

A series of cases involving refugees like $\mathrm{Joe}^{2}$ has drawn the attention of the federal courts to the question of neutrality as political opinion. The Ninth Circuit began the debate by classifying neutrality as political opinion. ${ }^{3}$ Later, the Eleventh Circuit suggested that if faced with the question, it would rule that political neutrality cannot qualify as a political opinion. ${ }^{4}$ Other courts have declined to follow either lead and have cautiously sought some middle ground. ${ }^{5}$

In INS $v$ Elias-Zacarias, a case with facts similar to Joe's situation, the Supreme Court held that a guerrilla organization's attempt to coerce a person into performing military service does not necessarily constitute persecution on account of political opinion. $^{6}$ While it did not explicitly decide whether political neutrality qualifies as a political opinion under the Refugee Act, the Court did offer important insights into the proper statutory interpretation of the Act and the proper standard of judicial review.

This Comment proposes a post-Elias-Zacarias standard under which neutrality qualifies as a political opinion under the Refugee Act in two instances: either the refugee chooses to be neutral for political reasons, or the persecutor mistakenly imputes a political opinion to the non-politically motivated neutral. This standard, borrowing from a standard proposed by the First Circuit, harmonizes the Ninth Circuit's overly broad interpretation of neutrality as political opinion with the Eleventh Circuit's overly narrow approach.

2 The classic examples are refugees from El Salvador. As of the writing of this Comment, an uncharacteristic calm has settled over Central America in general and El Salvador in particular. While one certainly hopes that the issues addressed in this Comment will soon be merely interesting legal questions devoid of any real importance, the historic instability of Central America, as well as recent civil strife in Haiti, Yugoslavia, and Somalia, counsel that a workable standard for adjudicating asylum claims based on political neutrality will unfortunately remain of great practical significance.

${ }^{3}$ See Bolanos-Hernandez v INS, 767 F2d 1277, 1286 (9th Cir 1985).

4 See Perlera-Escobar $v$ Executive Office for Immigration, 894 F2d 1292, 1297-98 (11th Cir 1990). The court noted "the fact" that treating a neutral position as a "political opinion" for purposes of the Refugee Act "would create a sinkhole that would swallow the rule." Id at 1298, citing Umanzor v Lambert, 782 F2d 1299, 1303 n 5 (5th Cir 1986).

${ }_{5}$ See, for example, Matter of Maldonado-Cruz, 19 I \& N Dec 509 (BIA 1988); NovoaUmania $v$ INS, 896 F2d 1 (1st Cir 1990).

6112 S Ct 812, 816 (1992). 
Section I explores the language and legislative history of the Refugee Act and explains how the Refugee Act represents a response to perceived defects in the Immigration and Nationality Act of 1952 ("Immigration Act"). "Section II examines the Supreme Court's recent decision in Elias-Zacarias, which touches on, but does not expressly decide, whether neutrality can constitute political opinion under the Refugee Act. Section III describes the varied approaches of the circuit courts of appeals and the Board of Immigration Appeals ("BIA"). Finally, Section IV reviews the viability of these approaches in light of Elias-Zacarias and argues for three main propositions. First, circuit courts need not automatically defer to BIA interpretations of the Refugee Act's political opinion provisions. Second, an alien who affirmatively chooses neutrality for political reasons is entitled to refugee status if the complained-of persecution occurred because the persecutor disliked neutrals, the alien refused to adopt the persecutor's political opinions, or the persecutor misinterpreted the alien's neutrality to be an expression of support for the persecutor's enemy. Third, if the alien's neutrality was not politically motivated, he is entitled to refugee status only if the persecutor misinterpreted his stance as political.

\section{The REFugee ACT OF 1980}

Congress passed the Refugee Act of 1980 in part to modernize American immigration law, which many felt had become inappropriately geographically and ideologically biased, as well as overly discretionary. ${ }^{8}$ The Act marked a major shift from the "restrictive and xenophobic immigration policy embodied in the national origins system and codified in the Immigration and Nationality Act of 1952." Although the 1965 amendments to the Immigration Act had replaced the old national origins system with a priority system based mainly on family reunification and job skill criteria, refugee policy remained riddled with ideological and geographic restrictions. ${ }^{10}$

7 Pub L No 82-414, 66 Stat 163 (1952), codified at 8 USC $\$ \S 1101$ et seq (1988).

8 See generally Deborah E. Anker and Michael H. Posner, The Forty Year Crisis: A Legislative History of the Refugee Act of 1980, 19 San Diego L Rev 9, 43-64 (1981).

$\checkmark$ Id at 10. Few today would endorse such a policy. But see Patrick Buchanan, quoted in Newsweek 17 (Dec 23, 1991) ("Ilf we had to take a million immigrants in, say, Zulus next year, or Englishmen, and put them in Virginia, what group would be easier to assimilate and would cause less problems ... ?").

${ }_{10}$ See Anker and Posner, 19 San Diego L Rev at 18. For example, refugee protection was only available to those who had fled from persecution in a "Communist or Commu- 
The Refugee Act of 1980 changed this system, first and foremost, by defining the term "refugee" in an unbiased manner. Under the Act, "refugee" includes any person who is unable or unwilling to return to his home country "because of persecution or a well-founded fear of persecution on account of race, religion, nationality, membership in a particular social group, or political opinion."11 The Refugee Act then applies this definition to those seeking asylum; ${ }^{12}$ similar requirements apply to those seeking a withholding of deportation. ${ }^{13}$

The drafters of the Refugee Act sought to harmonize the United States's definition of refugee with the definition set out in the United Nations Convention and Protocol Relating to the Status of Refugees ("Protocol"). ${ }^{14}$ Accordingly, the Refugee Act's definition of refugee is essentially the same as the United Nations's. ${ }^{15}$ Unfortunately, neither the Refugee Act nor the Protocol defines "political opinion." As a result, the courts have been left to determine on their own the meaning and scope of the Act's "political opinion" provisions and whether neutrality qualifies as such political opinion.

nist-dominated country" or a "country within the general area of the Middle East." Immigration and Nationality Act Amendments of 1965, Pub L No 89-236, § 3(a)(7), 79 Stat 911, 913 (1965), codified at 8 USC $\S 1153(a)(7)$ (1976 \& Supp 1979). While refugee admission was also allowed for "persons uprooted by catastrophic natural calamity," id, this provision was never used. See Thomas Alexander Aleinikoff and David A. Martin, Immigration: Process and Policy $709 \mathrm{n} 11$ (West, 2d ed 1991).

118 USC \$ 1101(a)(42)(A).

128 USC \& 1158(a). An alien may petition for asylum to an Asylum Officer with the Immigration and Naturalization Service ("INS"), 8 CFR § 208.2(a) (1992), or, in certain circumstances, an Immigration Judge with the Executive Office of Immigration Review ("EOIR"). 8 CFR $\S 208.2$ (b) (1992). A denial of asylum is appealable to the BIA, 8 CFR $\S$ 3.1(b) (1992), and BIA determinations are appealable to the United States Court of Appeals. 8 USC \$ 1105a(a).

138 USC $\$ 1253(h)(1)$. Petitions for withholding of deportation follow procedures similar to those for asylum applications. 8 CFR \& 208.3(b) (1992). The primary difference is that the Attorney General has no discretion to deport an alien who meets the definition of refugee if he shows a "clear probability" that his "life or freedom would be threatened" in his homeland. See INS $v$ Cardoza-Fonseca, 480 US 421, 429-30 \& n 9 (1987), citing 8 USC $\S 1253(\mathrm{~h})(1)$.

14 See Refugee Act of 1980, S Rep No 96-590, 96th Cong, 2d Sess 19 (1980); The Refugee Act of 1979, S Rep No 96-256, 96th Cong, 1st Sess 14-15 (1979); The Refugee Act of 1979, HR Rep No 96-608, 96th Cong, 1st Sess 9 (1979). See also Anker and Posner, 19 San Diego $L$ Rev at 60-61 (cited in note 8).

${ }^{15}$ See INS v Cardoza-Fonseca, 480 US at 436-41. 


\section{INS V ELIAS-ZACARIAS}

The Supreme Court brushed upon the issue of neutrality as political opinion in INS $v$ Elias-Zacarias. ${ }^{16}$ In Elias-Zacarias, a Guatemalan citizen sought asylum and withholding of deportation because of his fear of persecution from anti-government guerrillas on account of his refusal to join them. ${ }^{17}$ Elias-Zacarias testified that armed guerrillas visited his home one night and attempted to coerce him and his parents into joining their army. ${ }^{18}$ Elias-Zacarias told the Immigration Judge hearing the case that he "did not want to join the guerrillas because the guerrillas are against the government and he was afraid that the government would retaliate against him and his family if he did join the guerrillas."19

The Immigration Judge concluded that Elias-Zacarias had not made the requisite showing of a "well-founded fear" of persecution on account of political opinion and dismissed his claims. ${ }^{20}$ The Ninth Circuit reversed the Immigration Judge's ruling on the asylum claim, holding that Elias-Zacarias had evidenced a well-founded fear of conscription by the guerrillas-a political organization persecuting for political reasons. ${ }^{21}$

The Supreme Court, having granted certiorari to address the relatively narrow issue of "whether a guerrilla organization's attempt to coerce a person into performing military service necessarily constitutes 'persecution on account of . . . political opinion' under $\S 101(\mathrm{a})(42)$ of the Immigration and Nationality Act,"22 reversed the Ninth Circuit and held that the "generalized" political motivation underlying the dragooning tactics of the Guatemalan guerrillas did not "establish ... the proposition that EliasZacarias fears persecution on account of political opinion, as $\S$ 101(a)(42) requires." ${ }^{\prime 23}$ The Ninth Circuit had held that conscription by a guerrilla group necessarily constitutes persecution on account of political opinion because "the person resisting forced

16112 S Ct 812 (1992).

17 Id at 814-15.

18 Id at 814.

19 Id.

20 Id at 815.

${ }^{21}$ Zacarias $v$ United States INS, 921 F2d 844, 851-52 (9th Cir 1990). Although the Ninth Circuit held that Elias-Zacarias had satisfied the "well-founded fear" element of his asylum claim, the court agreed with the Immigration Judge's finding that there was not evidence of the "clear probability" of persecution necessary to support a withholding of deportation. Id.

$22112 \mathrm{~S} \mathrm{Ct}$ at 814 .

23 Id at 816 . 
recruitment is expressing a political opinion hostile to the persecutor and because the persecutors' motive in carrying out the kidnapping is political." ${ }^{.24}$ To this, the Court replied, "[t] $]$ he first half of this seems to us untrue, and the second half irrelevant.".25

The Court thus overruled an important element of Ninth Circuit refugee law-the presumption that forced recruitment by a group with political goals necessarily equals political persecution. ${ }^{26}$ According to the Court, the phrase "persecution on account of . . p political opinion" means "persecution on account of the victim's political opinion, not the persecutor's."27 The Court held that the guerilla's underlying political agenda did not establish persecution on account of political opinion; the forced recruitment feared by Elias-Zacarias would likely "be engaged in by the guerrillas in order to augment their troops rather than show their displeasure" at Elias-Zacarias's non-acquiescence. ${ }^{28}$

Despite its proximity to the question of whether political neutrality can constitute political opinion under the Refugee Act, the Court declined to rule on that issue..$^{29}$ The Court did note, however, that while "Elias-Zacarias appears to argue that not taking sides with any political faction is itself the affirmative expression of a political opinion[, t] hat seems to us not ordinarily so ...."30 The Court also emphasized that the concept of "political opinion" under the Refugee Act must be distinguished "from such quite different concepts as indifference, indecisiveness and risk-averseness." ${ }^{\prime 31}$

Moreover, even if a person based an asylum claim on political neutrality, the Court implied that he would have to have chosen neutrality for political reasons. The Court reasoned that:

${ }^{24}$ Zacarias, 921 F2d at 850.

25 Elias-Zacarias, $112 \mathrm{~S}$ Ct at 815.

${ }_{26}$ See Arteaga v INS, 836 F2d 1227, 1232 n 8 (9th Cir 1988); Maldonado-Cruz v Dept of Immigration and Naturalization, 883 F2d 788, 791 (9th Cir 1989); Zacarias, 921 F2d at 850.

${ }^{27}$ Elias-Zacarias, $112 \mathrm{~S} \mathrm{Ct}$ at 816 , quoting $8 \mathrm{USC}$ § 1101(a)(42).

${ }^{28}$ Id at $816 \& \mathrm{n} 2$.

29 [W] need not decide whether the evidence compels the conclusion that EliasZacarias held a political opinion. Even if it does, Elias-Zacarias still has to establish that the record also compels the conclusion that he has a 'well-founded' fear that the guerrillas will persecute him because of that political opinion, rather than because of his refusal to fight with them .... [H]e has not done so at all.

Id at 816 .

so Id.

31 Id. 
Even a person who supports a guerrilla movement might resist recruitment for a variety of reasons-fear of combat, a desire to remain with one's family and friends, a desire to earn a better living in civilian life, to mention only a few. The record in the present case not only failed to show a political motive on Elias-Zacarias' part; it showed the opposite. $^{32}$

In a spirited dissent, Justice Stevens, joined by Justices Blackmun and O'Connor, criticized the majority's "narrow, grudging construction of the concept of "political opinion." 33 The dissenters would have adopted the Ninth Circuit's approach and held that "[a] refusal to support a cause . . . can express a political opinion as effectively as an affirmative statement or affirmative conduct." ${ }^{\prime 34}$ Further, the dissenters maintained that a refusal to support a cause need not be politically motivated to merit a grant of asylum. ${ }^{35}$

\section{NEUTRALITY As POLITICAL OPINION}

Although Elias-Zacarias does reflect a certain skepticism toward neutrality claims, the holding ultimately rested on EliasZacarias's failure to meet his burden of proof. The Court's comments on whether "not taking sides" is an expression of political opinion are clearly dicta. Consequently, whether neutrality can be a political opinion remains an open question for lower courts. The issue has been directly addressed only by the BIA and the Ninth Circuit. Additionally, the First and Eleventh Circuits have discussed this question in dicta. ${ }^{36}$

32 Id at 815-16.

33 Id at 818 (Stevens dissenting).

31 Id (Stevens dissenting).

${ }^{35}$ Id (Stevens dissenting) ("Even if the refusal is motivated by nothing more than a simple desire to continue living an ordinary life with one's family, it is the kind of political expression that the asylum provisions of the statute were intended to protect.").

${ }^{36}$ The Fourth Circuit has also adjudicated cases raising the issue of neutrality as political opinion, but has decided these cases on other grounds. Still, dicta in these cases reflects some hostility toward the Ninth Circuit conception of "political opinion." For example, in Cruz-Lopez v INS, 802 F2d 1518, 1521 (4th Cir 1986), the court noted that "Cruz-Lopez's position [that of refusing to join an El Salvadoran guerrilla group] is no different from that of many young, urban males 'invited' to join guerrilla groups. Unfortunately, this country cannot serve as a haven for all of them." See also Figeroa $v$ INS, 886 F2d 76, 80-81 (4th Cir 1989) (stating that a generalized fear of persecution by both sides in civil conflict for remaining neutral "reflect[s] the dangers faced by virtually all young $E]$ Salvadoran males"); M.A. A26851062 v INS, 899 F2d 304, 316 (4th Cir 1990) (noting that the Refugee Act does not recognize asylum eligibility for those who merely fear general 


\section{A. The Ninth Circuit: Neutrality Constitutes Political Opinion}

Since 1985, the Ninth Circuit has repeatedly affirmed that neutrality is a political opinion for purposes of the Refugee Act and that persecution or fear of persecution relating to such neutrality will ordinarily warrant asylum relief. ${ }^{37}$ According to the court in Bolanos-Hernandez $v$ INS, "[c]hoosing to remain neutral is no less a political decision than is choosing to affiliate with a particular political faction.... When a person is aware of contending political forces and affirmatively chooses not to join any faction, that choice is a political one. ${ }^{38}$

As noted above, this recognition of neutrality as a protected form of political opinion was not explicitly overruled by EliasZacarias. The Ninth Circuit's methods for granting asylum relief premised upon neutrality have, however, been called into question to varying degrees by the Elias-Zacarias decision.

The Ninth Circuit's policy of granting asylum relief in neutrality cases is an extremely generous one, demanding little of the applicant. First, neutrality need not be chosen for political reasons. ${ }^{39}$ The Bolanos-Hernandez court reasoned that an inquiry into a person's motivation for choosing neutrality is improper, imprecise, and irrelevant: "The guerrillas in El Salvador do not inquire into the reasoning process of those who insist on remaining neutral and refuse to join their cause. They are concerned only with an act that constitutes an overt manifestation of a

violence in war-torn El Salvador).

${ }^{37}$ Since the passage of the Refugee Act in 1980, the Ninth Circuit has played a particularly significant role in interpreting the Act's provisions. See generally Carolyn P. Blum, The Ninth Circuit and the Protection of Asylum Seekers Since the Passage of the Refugee Act of 1980, 23 San Diego L Rev 327, 328-39 (1986).

The decisions of the Ninth Circuit regarding the parameters of "political opinion" are of great importance not only because of their innovative and often expansive readings of the provisions of the Refugee Act, but also because the Circuit is responsible for more published decisions interpreting the Act than any other circuit. See id at $329 \mathrm{n} 12$ (noting that the Ninth Circuit is responsible for over $40 \%$ of the published decisions interpreting the Refugee Act as of 1986); Comment, Perlera-Escobar v. Executive Office for Immigration: Political Asylum and the Question of Neutrality, 18 Brooklyn J Intl L 251, 255 \& n 20 (1992) (noting that a large majority of asylum applications are decided in the Ninth Circuit).

${ }^{38} 767$ F2d 1277, 1286 (9th Cir 1985). Bolanos, a former member of a right-wing political party and the El Salvadoran military, had testified that he was threatened with death after refusing to join an anti-government guerrilla group due to "his desire to remain neutral and not be affiliated with any political group." Id at 1280 . The Ninth Circuit panel reversed the decision of the BIA, which, like the INS, had denied Bolanos's application for political asylum and withholding of deportation. Id.

${ }^{39}$ For a discussion of victims' political motivation after Elias-Zacarias, see text accompanying notes 98-109. 
political opinion." ${ }^{30}$ While thus acknowledging that neutrality may be chosen for non-political reasons, the Bolanos-Hernandez court held that "[w] hatever the motivation, an individual's choice, once made, constitutes, for better or for worse, a manifestation of political opinion," and that "[p]ersecution because of that overt manifestation is persecution because of a political opinion." ${ }^{\prime 4}$

Second, an asylum seeker need not even express his neutrality to his persecutor. ${ }^{42}$ As long as the applicant affirmatively chooses neutrality and makes an overt act from which neutrality can be inferred, the fact that he never articulates his neutrality is irrelevant. ${ }^{43}$

Third, so long as the persecutor has an underlying political agenda, the persecutor's specific motivation is irrelevant. ${ }^{44}$ This premise is most relevant in forced recruitment cases, where it often appears that guerrilla dragooning efforts are motivated by a desire to augment troop strength rather than punish political enemies. ${ }^{45}$ In Arteaga $v$ INS, the Ninth Circuit considered it irrelevant that the guerrillas may have conscripted the petitioner to fill their ranks rather than punish his neutrality: "Clearly, forced recruitment into the war against the government is politically motivated." ${ }^{\prime 6}$ Recognizing that courts generally reject persecution claims premised on conscription into a foreign government's national army, ${ }^{47}$ Arteaga held:

40 Bolanos-Hernandez, 767 F2d at 1287.

4 Id.

12 Argueta $v$ INS, 759 F2d 1395, 1397 (9th Cir 1985). The petitioner in Argueta testified that four Death Squad members had falsely accused him of being a member of the FPL, an anti-government guerrilla organization, and threatened him with "disappearance" if he did not leave the country. Id at 1395-96. The court held that the petitioner affirmatively chose neutrality, even though he never expressed this opinion to his alleged persecutors. Id at 1397.

43 See Bolanos-Hernandez, $767 \mathrm{~F} 2 \mathrm{~d}$ at 1286-87.

4 See Zacarias, 921 F2d at 850,852 . This issue was addressed and overruled in Elias-Zacarias. See text accompanying notes 16-32.

45 As in Elias-Zacarias. See $112 \mathrm{~S} \mathrm{Ct}$ at $816 \mathrm{n} 2$.

46836 F2d 1227, 1232 n 8 (9th Cir 1988). See also Del Valle $v$ INS, 776 F2d 1407 (9th Cir 1985). In Del Valle, a petitioner for asylum and withholding of deportation testified that after rejecting repeated offers to become an informer for a right-wing group known as the "Squadron of Death" he was abducted and beaten by members of the group. Id at 1409-10. The court held, without finding it necessary to inquire into the group members' motives, that "Del Valle's refusal, in combination with his deliberate non-involvement prior to his refusal, does evidence [expression of political opinion]." Id at $1414 \mathrm{n} 5$.

${ }^{7}$ See Kaveh-Haghigy $v$ INS, 783 F2d 1321, 1323 (9th Cir 1986) (holding that potential conscription into the Iranian army was not persecution: "Absent exceptional circumstances, it is not the place of the judiciary to evaluate the political justifications of the actions of foreign governments"); Glavic v Beechie, 225 F Supp 24, 27 (S D Tex 1963) (holding that required service in the Yugoslav national army is not the type of persecution 
Whatever justification exists for distinguishing between national military conscription and deprivations of freedom, such justification does not apply to actions of nongovernmental groups, which lack legitimate authority to raise armies by conscription. Forced recruitment by a revolutionary army is tantamount to kidnapping, and is therefore persecution. ${ }^{48}$

Finally, neutrality may constitute political opinion in the Ninth Circuit when a "persecutor falsely attributes an opinion to the victim, and then persecutes the victim because of that mistaken belief about the victim's views." ${ }^{\text {"49 }}$ This theory is known as the doctrine of imputed political opinion, and the Ninth Circuit has recently reaffirmed its vitality, noting that "[n]othing in Elias-Zacarias changes our analysis."

Within the doctrine of imputed political opinion, the Ninth Circuit has even held that the imputation of political opinion need not be genuine. ${ }^{51}$ In Lazo-Majano $v$ INS, the petitioner testified that she had fled to the United States because a sergeant in the El Salvadoran military had repeatedly raped and brutalized her, threatening to brand her a "subversive" and kill her if she reported him. ${ }^{52}$ While the court conceded that the sergeant probably never believed that Lazo-Majano was a subversive, it nonetheless held that a cynical and manipulative imputation of political opinion can transform a personal tragedy into political persecution. $^{53}$

that justifies parole into the United States). See also Selective Draft Law Cases, 245 US 366,378 (1918) (rejecting a claim that conscription is repugnant to a free government); Office of the United Nations High Commissioner for Refugees, Handbook on Procedures and Criteria for Determining Refugee Status $\$ 167$ at 39-40 (United Nations, 1988) ("Fear of prosecution and punishment for desertion or draft-evasion does not in itself constitute well-founded fear of persecution under the definition.").

Exceptions may arise, however, where the conscription is a pretext for imposing a disproportionately severe punishment on a person because of his race, religion, nationality, social group membership, or political opinion, or where the military service would force the alien to engage in "inhuman conduct." See Mark R. von Sternberg, Emerging Bases of "Persecution" in American Refugee Law: Political Opinion and the Dilemma of Neutrality, 13 Suffolk Transnatl L J 1, 48 (1989).

48 Arteaga, $836 \mathrm{~F} 2 \mathrm{~d}$ at 1232.

49 Canas-Segovia v INS, 970 F2d 599, 601-02 (9th Cir 1992).

50 Id.

51 For a discussion of insincerely imputed political opinion, see text accompanying notes 120-24.

52813 F2d 1432, 1433 (9th Cir 1987).

${ }_{53}$ Id at 1435-36. See also Desir $v$ Ilchert, 840 F2d 723, 729 (9th Cir 1988) ("Desir's actual political view at the time ... is not relevant to our assessment of his refugee status [because his persecutors had falsely attributed one to him]."). 
Although Elias-Zacarias overruled some aspects of the Ninth Circuit's view of neutrality, the Ninth Circuit continues to treat neutrality as a political opinion for purposes of the Refugee Act in two situations: when a person is persecuted for affirmatively maintaining a neutral stance, ${ }^{54}$ or when a persecutor imputes a political opinion to a person and attacks him because of it. ${ }^{55}$ Furthermore, despite language to the contrary in Elias-Zacarias, ${ }^{56}$ the Ninth Circuit apparently still does not require that an alien's neutrality be politically motivated. ${ }^{57}$

\section{B. The Eleventh Circuit: Neutrality Does Not Constitute Political Opinion}

At the other pole lies the Eleventh Circuit, which has indicated that it approves of the position that political neutrality should never constitute a political opinion. The Eleventh Circuit's first and only published opinion discussing the issue came in Perlera-Escobar $v$ Executive Office for Immigration. ${ }^{58}$

In Perlera-Escobar, the petitioner testified that he was politically neutral in the ongoing civil war in his homeland but had been unwillingly caught up in the strife. Escobar claimed that he feared persecution by the government for being a rebel and persecution by the guerrillas for being a deserter. ${ }^{59}$ The Eleventh Circuit deferred to the BIA's decision that the facts of the case did not support a claim of persecution on account of political opinion. $^{60}$ In so doing, the Perlera-Escobar court noted that

54 This stance can be manifested either by an affirmative decision not to join any political faction, see Argueta, 759 F2d at 1397, or by an affirmative refusal to accept an "invitation" to join a particular side. See Bolanos-Hernandez, 767 F2d at 1287 ("By choosing neutrality and refusing to join a particular political faction, Bolanos expressed his opinion and took a political stance."); Del Valle, 776 F2d at 1414 ("When approached on several occasions, by the Squadron of Death, he did not accept their invitation to join. Del Valle has therefore made a considered choice to take a neutral stance...."); MaldonadoCruz, 883 F2d at 791-92 (Where the petitioner had escaped from an El Salvadoran guerrilla camp after forcible conscription, his "refusal to join [the guerrillas] was a manifestation of his neutrality, which is a recognized political opinion.").

ss As noted above, this imputation can be genuine or contrived. See text accompanying notes 49-53.

${ }_{56}$ See text accompanying notes 104-09.

${ }^{57}$ See Canas-Segovia, 970 F2d at 601-02. In this case, subsequent to Elias-Zacarias, the Ninth Circuit acknowledged the Supreme Court's requirement that political motivation on the part of the persecutor be shown. In considering this requirement to be satisfied by imputed political opinion, however, the Canas-Segovia court implicitly held that the petitioner was entitled to political asylum even though his refusal to serve in the El Salvadoran armed forces was motivated by his religious, rather than political, beliefs.

s3 894 F2d 1292 (11th Cir 1990).

69 Id at 1294.

6o Id at 1299. In support of this deference, the court commented that "[w] hat consti- 
"[t]his circuit has not adopted the Ninth Circuit's belief that political neutrality is a political opinion for purposes of the Act." Such an interpretation would, in the Eleventh Circuit's view, "create a sinkhole that would swallow the rule."62

The Perlera-Escobar court also declined to apply the Ninth Circuit's imputed political opinion doctrine to neutrals. In exploring the motivation of the guerrillas in persecuting Escobar, the court argued that "the guerrillas care not what Escobar thinks or believes; rather their interest in him stems from their need to preserve unity and order in their ranks and to ensure the secrecy of their operations." ${ }^{\text {63 }}$ Thus, under the Eleventh Circuit approach, not even politically motivated or politically labelled neutrals would qualify for asylum based on their well-founded fears.

\section{The BIA: Neutrality May Constitute Political Opinion Under Some Circumstances}

The Board of Immigration Appeals has adopted neither the Ninth Circuit's broad view of neutrality as political opinion nor the Eleventh Circuit's prohibitive view. ${ }^{64}$ Instead, the BIA appears to assume that neutrality may constitute political opinion under the Refugee Act. ${ }^{65}$ However, the BIA then holds applicants to a very strict standard of proof; in its two published opin-

tutes a political opinion under the Act is a political question which the courts are not especially qualified to decide." Id. For a criticism of the view that the proper interpretation of "political opinion" under the Refugee Act is a non-justiciable political question, see Comment, 18 Brooklyn J Intl L at 263-70 (cited in note 37).

61894 F2d at 1297 n 4. Still, the Perlera-Escobar court declined to rule "whether 'no opinion' constitutes an opinion under the Act because even assuming that it does, Escobar never openly articulated his position, nor has he shown that the guerrillas pursue him because of his neutrality." Id at 1298, citing Arteaga v INS, 836 F2d 1227 (9th Cir 1988).

62 Id at 1298.

63 Id. Perlera-Escobar may be distinguished from Arteaga on the grounds that the BIA in Perlera-Escobar did not believe that Escobar was forcibly recruited. See id at 1297 n 4. Nonetheless, the Perlera-Escobar court created a rebuttable presumption (or at least happily deferred to a BIA presumption) that revolutionary armies exercise control over their troops for non-political reasons. Id at 1298-99. This differs from the Arteaga presumption that actions of a political faction in furtherance of its political goals are necessarily politically motivated. See Arteaga, 836 F2d at 1232 n 8.

64 In adjudicating asylum and withholding of deportation claims, the BIA is only obligated to follow the decisions of the federal appellate court for the circuit in which it sits. In those circuits in which the federal appellate court has not decided an issue, the BIA may apply its own standard. Because only the Ninth Circuit has definitively ruled on the question of neutrality as political opinion, the BLA remains free to apply its own standard in all other jurisdictions.

${ }_{65}$ See Matter of Maldonado-Cruz, 19 I \& N Dec 509, 516 (BIA 1988); Matter of Vigil, 19 I \& N Dec 572, 576 (BIA 1988). 
ions dealing with neutrality as political opinion, the BIA did not grant relief.

The BIA position places three requirements on neutral asylum-seekers. First, the applicant must hold a "principled position of neutrality. ${ }^{266}$ While the BIA in Matter of Maldonado-Cruz did not elaborate meaningfully on what makes a neutrality position "principled," the BIA implied that neutrality must be a conscious, politically motivated choice and not merely the absence of a political view. Second, the applicant must have expressed his neutrality publicly. ${ }^{67}$ While the applicant for political asylum in In re Vigil had made a principled decision to remain neutral in the El Salvadoran civil war, the BIA found it significant that he had not expressed this view to anyone..$^{68}$ Finally, the alien's neutrality must be the direct cause of the complained-of persecution. Unless the victim "has received some threat or could be 'singled out' for persecution because of [his] neutrality opinion," his plight does not qualify as persecution on account of political opinion under the Refugee Act. ${ }^{69}$ Therefore, if the persecutor merely seeks to enforce military discipline by punishing desertion, ${ }^{70}$ or augment guerrilla troop strength through forced recruitment, ${ }^{71}$ relief under the Refugee Act is unavailable.

\section{The First Circuit: A Hypothetical Middle Ground}

Although it has not ruled on the question of neutrality as political opinion, the First Circuit discussed the issue in dicta in Novoa-Umania $v$ INS. ${ }^{72}$ There, the court proposed a standard of review narrower than the Ninth Circuit's standard but broader than the BIA's. In Novoa-Umania, an El Salvadoran citizen testified that both the government and the anti-government guerrillas had threatened to kill him because each interpreted his "neutrality" as support for the other side. ${ }^{73}$ As did the BIA, the court assumed that neutrality could constitute political opinion. ${ }^{74}$ The court then interpreted the statutory definition of "refugee" to require that an asylum petitioner claiming persecution

\footnotetext{
66 Maldonado-Cruz, 19 I \& N Dec at 516.

67 See Vigil, 19 I \& N Dec at 576-77.

68 Id at 577 .

69 Id at 576.

${ }^{70}$ See Maldonado-Cruz, 19 I \& N Dec at 514-15.

7 See Vigil, 19 I \& N Dec at 577-78.

72896 F2d 1 (1st Cir 1990).

73 Id at 2-3.

74 Id at 3.
} 
on account of political neutrality be able to demonstrate a wellfounded fear of one of the following:

1) that a group with the power to persecute him intends to do so specifically because the group dislikes neutrals, or 2) that such a group intends to persecute him because he will not accept its political point of view, or 3) that one or more groups intend to persecute him because each (incorrectly) thinks he holds the political views of the other side. ${ }^{75}$

The court held that the petitioner failed to meet any prong of this test. $^{76}$ Thus, under the First Circuit approach, a petitioner's expression of neutrality is entitled to Refugee Act protection if the three-part-Novoa-Umania test indicates that the expression is linked to traditional political persecution.

\section{A WORKaBle STANDARD FOR NeUTRALITY AS POLITICAL OPINION}

As discussed earlier, the Elias-Zacarias opinion does not resolve the question of whether neutrality may ever constitute a political opinion under the Refugee Act. Nonetheless, EliasZacarias does offer important insights into this issue. First, the case indicates that the question of whether neutrality constitutes political opinion under the Refugee Act is a legal question that does not require automatic deference to Immigration Judge and BIA determinations. Second, Elias-Zacarias implies that the "political opinion" provisions of the Refugee Act, properly interpreted, allow neutrality to constitute political opinion under some circumstances.

Recognizing that neutrality constitutes political opinion under some circumstances does not, however, tell us what these circumstances are. This Comment argues that the First Circuit's hypothetical test answers this question, providing a useful standard for adjudicating asylum and withholding-of-deportation claims premised upon political neutrality. Under this test, a victim can receive relief only if the persecutor sought to punish the victim because (1) the persecutor dislikes neutrals, (2) the victim refused to conform his ideas to those of his persecutor, or

75 Id.

${ }^{76}$ Id at 3-4. See also Alvarez-Flores $v$ INS, 909 F2d 1, 6-7 (1st Cir 1990). The court there assumed, but did not decide, that neutrality could constitute a political opinion; applying the three-part Novoa-Umania test, the court concluded that the petitioner did not qualify for asylum. Id. 
(3) the persecutor wrongly interpreted the victim's neutrality to be support for the persecutor's enemy. Finally, the Comment supplements this test by suggesting that the victim must have a political motive for choosing neutrality under elements (1) and (2), but not element (3). Under element (3), however, the persecutor's mistake must be genuine.

\section{A. Judicial Deference}

Before positing substantive legal standards for the circuit courts to utilize in deciding asylum cases premised on political neutrality, one must first determine whether judicial review is warranted at all. Courts, of course, do not have free rein in revisiting the decisions rendered by administrative agencies such as the BIA. This is especially true regarding agency findings of fact. Indeed, the Elias-Zacarias Court noted that the BIA's factual determinations "can be reversed only if the evidence presented ... was such that a reasonable factfinder would have to conclude that the requisite fear of persecution existed." ${ }^{\prime 7}$ However, while much of the initial determination of an alien's eligibility for relief under the Refugee Act involves mixed questions of fact and law ${ }^{78}$ interpreting the scope of the "on account of political opinion" clause of the Act would seem to be a purely legal question. Unlike garnering facts or judging credibility, tasks for which the BIA unquestionably has a special competence, there is no reason to believe that the BIA has special expertise in the statutory interpretation of terms of art such as "political opinion."

The beginning point for any inquiry into an administrative agency's legal determination is Chevron, U.S.A. $v$ Natural Resources Defense Council. ${ }^{79}$ Cheuron laid down the following standard for judicial review of statutory construction by agencies:

First, always, is the question whether Congress has directly spoken to the precise question at issue. If the intent of Congress is clear, that is the end of the matter; for the court, as well as the agency, must give effect to the unambiguously expressed intent of Congress. If, however, ... the statute is silent or ambiguous with respect to the specific issue, the

$77112 \mathrm{~S}$ Ct at 815.

${ }^{78}$ Note, Persecution on Account of Political Opinion: "Refugee" Status After INS v. Elias-Zacarias, 112 S. Ct. 812 (1992), 67 Wash L Rev 959, 961 (1992).

79467 US 837 (1984). 
question for the court is whether the agency's answer is based on a permissible construction of the statute. ${ }^{80}$

Lower courts have divided on whether Congress expressed a clear intent in the Refugee Act with regard to persecution on account of political opinion. The First, Fifth and Eleventh Circuits have concluded that Congress was ambiguous or expressed no intent that the provisions of the Refugee Act be interpreted in a particular way. Thus, these circuits have deferred to the BIA's interpretation of the Act. ${ }^{81}$ The Ninth Circuit, on the other hand, has not adopted this hands-off approach. Ninth Circuit panels have routinely indicated that they can ascertain congressional intent using ordinary methods of statutory construction, and they have reviewed BIA interpretations of the Refugee Act de novo. ${ }^{82}$

In Elias-Zacarias, the Court implicitly ratified the Ninth Circuit view by using a "plain meaning" approach to the political opinion provision at issue. Although the Court reversed the Ninth Circuit decision in Elias-Zacarias, the Court did not hold that the Ninth Circuit should have deferred to the BIA's legal interpretation. Rather, the Court held that the Ninth Circuit had erroneously construed the Refugee Act's political opinion provision. The Court noted that "[i]n construing statutes, "we must, of course, start with the assumption that the legislative purpose is expressed by the ordinary meaning of the words used." Court held that the ordinary meaning of "persecution on account of political opinion" is clear: the phrase necessarily refers to "persecution on account of the victim's political opinions, not the persecutor's," and "political opinion" does not ordinarily include neutrality. ${ }^{84}$

so Id at 842-43 (footnotes omitted).

81 See Alvarez-Flores, 909 F2d at 3-4; Campos-Guardado $v$ INS, 809 F2d 285, 289-90 (5th Cir 1987); Perlera-Escobar, 894 F2d at 1296 ("The meaning and scope of the phrase 'on account of ... political opinion' is not defined by the Act, nor does it appear ... that Congress unambiguously expressed an intent that the term should be construed in a particular way."). See also Note, Persecution Based on Political Opinion: Interpretation of the Refugee Act of 1980, 25 Cornell Intl L J 231, 238 (1992).

${ }_{82}$ See Canas-Segovia v INS, 902 F2d 717, 721 (9th Cir 1990), vacated, INS v CanasSegovia, 112 S Ct 1152 (1992); Maldonado-Cruz, 883 F2d at 791; Arteaga, 836 F2d at 1228; Desir, 840 F2d at 726. See also Note, 25 Cornell Intl L J at 237-38.

${ }_{83}$ Elias-Zacarias, $112 \mathrm{~S} \mathrm{Ct}$ at 816, quoting Richards $v$ United States, 369 US 1, 9 (1962).

${ }^{84}$ Elias-Zacarias, $112 \mathrm{~S} \mathrm{Ct}$ at 816 . This interpretation is a far cry from the axiomatic Ninth Circuit view that "[j]ust as a nation's decision to remain neutral is a political one, so is an individual's." Bolanos-Hernandez, 767 F2d at 1286 (citation omitted). 
The Court thus resolved the dispute among the circuits as to whether Congress spoke clearly on the meaning of "political opinion." Henceforth, neither lower courts nor the BIA may declare that Congress left the term ambiguous and up to the BIA to specify. Thus, only one question remains open for the courts and the BIA: under what, if any, out-of-the-ordinary circumstances may neutrality constitute political opinion?

\section{B. Can Neutrality Ever Constitute Political Opinion?}

Although the Elias-Zacarias Court indicated that the Ninth Circuit had erroneously equated neutrality with political opinion, the Court did not hold that neutrality can never constitute political opinion under the Refugee Act. Instead, it merely stated that neutrality does not "ordinarily" constitute political opinion. ${ }^{85}$

While a bright-line rule that completely excludes neutrality from the Refugee Act's definition of political opinion might be easier to administer, such an approach cannot possibly comport with the ordinary meaning of the words "persecution on account of political opinion." How else would one classify the following colloquy?

Guerrilla: Do you support the government or our movement?

Civilian: I support neither. I disapprove of the policies and ideologies of both sides and remain firmly neutral in the current conflict.

Guerrilla: My comrades and I despise neutrals. We will kill you tomorrow because of your neutrality.

Certainly only the most "narrow, grudging construction of the concept of "political opinion" the above hypothetical faces persecution on account of his political opinions. Furthermore, while the Eleventh Circuit has not adopted the Ninth Circuit's view that neutrality constitutes political opinion, ${ }^{87}$ it has never been faced with the paradigm case presented above-where neutrality is not merely the absence of political opinion, but a carefully considered view of the political world. ${ }^{88}$

${ }^{85}$ Elias-Zacarias, $112 \mathrm{~S}$ Ct at 816.

${ }^{86}$ See id at 818 (Stevens dissenting).

${ }_{87}$ See Perlera-Escobar, 894 F2d at 1297 n 4.

83 In Perlera-Escobar, in fact, the court did not even have to affirmatively rule on the question of neutrality as political opinion because the petitioner's neutrality had not been 
Yet, while the Ninth Circuit in Bolanos-Hernandez appropriately rejected the position that neutrality is never political, the court went to the opposite extreme in asserting that informed neutrality is always political. It stretches the bounds of logic to imply, for example, that one who does not vote is necessarily making a political statement. A person might refrain from voting as a means of expressing displeasure with the political system in general or the candidates in particular; however, the non-voter might also be stating nothing more than that he ran out of gas on the way to the polling booth. ${ }^{89}$ Likewise, a person might choose a path of neutrality for purely personal reasons. Courts have generally held that "persecution" arising out of personal entanglements does not give rise to refugee status. ${ }^{90}$

Thus, the question of when neutrality constitutes political opinion under the Refugee Act remains open, and the extreme rules advocated by the Ninth and Eleventh Circuits are clearly unsatisfactory. It is possible, however, to arrive at an answer to the question by considering the Supreme Court's pronouncements on the extent to which the persecutor and victim must have political motives in order for the Refugee Act to afford protection to the victim.

established. In particular, "Escobar never openly articulated his position, nor has he shown that the guerrillas pursue him because of his neutrality." Id at 1298.

${ }_{89}$ Some might argue that this example is quite naive in that it "fails to come to grips with the realities of civil war." See, for example, von Sternberg, 13 Suffolk Transnatl L J at 26 (cited in note 47). While failure to vote in the context of a stable democracy could result as much from car trouble as from a particular political opinion, apolitical voter neutrality may be much less plausible in a country caught up in civil strife, where political questions permeate much of daily life.

While this observation might be true, it does not justify the imposition of a per se rule that failure to vote in a civil war-torn country is necessarily the expression of a political opinion. Furthermore, the Supreme Court has indicated that this is a fact-driven (rather than rule-driven) inquiry by noting that political opinion must be distinguished "from such quite different concepts as indifference, indecisiveness and risk-averseness." Elias-Zacarias, $112 \mathrm{~S} \mathrm{Ct}$ at 816.

${ }^{30}$ See, for example, Zayas-Marini v INS, 785 F2d 801, 805-06 (9th Cir 1986) (Where an alien maintained good relations with the Paraguayan government, but was threatened with death by two government officials for opposing their corrupt practices, the Ninth Circuit held that the alien was the victim of a personal falling-out, not political persecution.); Campos-Guardado, 809 F2d at 288-90 (Where a woman was threatened with harm by a former guerrilla if she revealed his prior rape of her, the Fifth Circuit held that the BIA's finding that the persecution was personal, not political, was not erroneous as a matter of law.). But see Comment, "Political Opinions" of Refugees: Interpreting International Sources, 63 Wash L Rev 395, 412 n 108 (1988) (arguing that the Campos-Guardado court could have legitimately found, as the Ninth Circuit did in Lazo-Majano, that Campos was persecuted as a result of political opinions imputed to her by her attackers). 


\section{Political Motivation of the Persecutor}

As an initial matter, Elias-Zacarias requires that the persecutor have a political motivation for threatening the neutral victim. As the Court held, "Elias-Zacarias still has to establish that ... he has a 'well-founded fear' that the guerrillas will persecute him because of [his] political opinion, rather than because of his refusal to fight with them."91

Whether the persecutor is politically motivated is a fact-specific inquiry. Elias-Zacarias failed to demonstrate that the guerrillas would persecute him on account of his political opinions rather than because of his refusal to join their army. While the Court would not require a refugee like Elias-Zacarias to provide direct evidence of the guerrillas' motives, because "the statute makes motive critical, he must provide some evidence of it, direct or circumstantial." ${ }^{\prime 2}$ The First Circuit's test suggests two forms of persecutor motivation to which a neutral asylum-seeker might point: first, that he suffered persecution because the persecutor disliked neutrals, and second, that he was persecuted because he refused to conform his ideas to the persecutor's.

Courts must, of course, defer to the fact-finder's assessment of the persecutor's motive. In Elias-Zacarias, the Court announced the standard of review as follows: if an alien "seeks to obtain judicial reversal of the BIA's determination, he must show that the evidence he presented was so compelling that no reasonable fact-finder could fail to find the requisite fear of persecution." ${ }^{\text {"3 }}$ Therefore, dragooning tactics employed by anti-government guerrillas, for example, do not necessarily constitute political persecution; the answer depends on the particular facts of the case. Thus, in Matter of Maldonado-Cruz, the BIA correctly searched the record for evidence of a political motivation on the part of the guerrillas in kidnapping the petitioner. ${ }^{94}$ Finding no such motive, the BIA determined that the petitioner had not been persecuted on account of political opinion. ${ }^{95}$ The Ninth Circuit

\footnotetext{
91 Elias-Zacarias, $112 \mathrm{~S} \mathrm{Ct}$ at 816.

92 Id at 816-17.

93 Id at 817.

is $19 \mathrm{I} \& \mathrm{~N}$ Dec 509, 514, 516 (BIA 1988).

95 Id at 516-17. Mark von Sternberg criticized the BIA's decision in Matter of Maldonado-Cruz for "fail [ing] to come to grips with the realities of civil war and ignor[ing] the intensification of political motivation which inevitably occurs when a country is thrown into a climactic stage of social violence." 13 Suffolk Transnatl L J at 26 (cited in note 47). Elias-Zacarias, however, indicates that such judicial notice of "the realities of civil war" is improper. See $112 \mathrm{~S}$ Ct at 816.
} 
overruled the BIA's determination, reasoning that "[ $t]$ he guerrillas are a political entity. Maldonado's refusal to join them was a manifestation of his neutrality, which is a recognized political opinion. Hence, any persecution by the guerrillas is a result of Maldonado's expression of his political opinion ...."96 Analyzed in light of Elias-Zacarias, the Ninth Circuit erred in failing to give appropriate deference to the BIA's factual determinations.

Elias-Zacarias also casts doubt upon the Ninth Circuit's presumption regarding the motives behind government persecution. In Hernandez-Ortiz v INS, for example, the Ninth Circuit held that where a government acts against an individual or members of a group and there is no "legitimate basis" for that action, there is a presumption that the government's action was politically motivated. ${ }^{97}$ Post-Elias-Zacarias, the Ninth Circuit would be safer in presuming nothing and looking to the facts in order to determine the government's motive.

\section{Political Motivation of the Victim and the Problem of Hecky Brown}

In the Woody Allen film The Front, ${ }^{98}$ a comedian named Hecky Brown is brought before the House Un-American Activities Committee ("HUAC") in the late 1950s and is accused of being a Communist. The only evidence on Brown was that he once marched in a leftist labor union's May Day parade. Brown explained that he had attended the march only to impress a young woman whose posterior dimensions he admired and who was a member of the union. HUAC did not accept his explanation and demanded that Brown identify other marchers for HUAC to investigate. When Brown did not comply, HUAC blacklisted him.

This scenario raises the following issue: assuming that HUAC's actions constituted "persecution" as we understand it under the Refugee Act, ${ }^{99}$ to what extent can we say that Brown was persecuted on account of his political opinions? All courts that have addressed the issue have agreed that neutrality must be an affirmative choice. One may not simply fail to adopt a polit-

96 Maldonado-Cruz, 883 F2d at 791 (citation omitted).

97777 F2d 509, 516 (9th Cir 1985).

ss Columbia Pictures, 1976.

99 Obviously, we must also pretend that Brown's "persecution" occurred in another country and he fled to the United States. 
ical position and then claim political persecution on account of neutrality. ${ }^{100}$

Under the Ninth Circuit standard, however, the choice to remain neutral need not be made for political reasons. The underlying political philosophy of the victim is of no concern, so long as he undertook an overt act constituting "neutrality."101 The overt act does not have to be the refusal of attempted conscription, although this is most common in the cases. Even a failure to act can meet the overt act requirement. In Desir $v$ Ilchert, for example, the petitioner failed to pay bribe money to low-level government security forces. ${ }^{102}$ The court held that "Desir's actual political view at the time, whether neutral or partisan, or his inability to pay, is not relevant to our assessment of his refugee status. ${ }^{103}$ Hecky Brown's overt act of marching in the parade would seem to constitute a political act under the Ninth Circuit standard. Regardless of why he acted, he acted overtly and, to all outward appearances, politically.

After Elias-Zacarias, however, Hecky appears to be out of luck. This is because the Court implied that the neutral victim must have chosen neutrality for political reasons in order to be eligible for asylum or withholding of deportation. The Court disagreed with the Ninth Circuit's reasoning that, by resisting forced recruitment, Elias-Zacarias had necessarily expressed a political opinion hostile to the guerrillas. ${ }^{104}$ To the contrary, "[t]he record ... not only failed to show a political motive on EliasZacarias' part; it showed the opposite."105

The Court listed some other impermissible grounds for claiming persecution on account of neutrality: "Even a person who supports a guerrilla movement might resist recruitment for a variety of reasons-fear of combat, a desire to remain with one's family and friends, a desire to earn a better living in civilian life, to mention only a few."106 The Court might very well have included a desire to impress a member of the opposite sex.

The Ninth Circuit in Bolanos-Hernandez had previously reasoned that "it is simply improper for the government to inquire into the motives underlying an individual's political deci-

\footnotetext{
100 See, for example, Lopez v INS, 775 F2d 1015, 1016-17 (9th Cir 1985).

101 See Bolanos-Hernandez, 767 F2d at 1286-87.

102840 F2d 723, 724-25 (9th Cir 1988).

${ }^{103}$ Id at 729.

104 Elias-Zacarias, $112 \mathrm{~S} \mathrm{Ct}$ at 815-16.

105 Id at 816.

106 Id at 815-16.
} 
sions.... [T]he motives frequently will be both complex and difficult to ascertain; it may not be possible to separate the political from the non-political aspects." 107 The Supreme Court rejected this position in Elias-Zacarias, where Justice Scalia betrayed no sense of impropriety in inquiring into Elias-Zacarias's motives. ${ }^{108}$ Indeed, the task of separating political from non-political motivation seems no more complex or difficult than many other permissible types of judicial fact-finding. ${ }^{109}$

Elias-Zacarias thus dictates that, in the typical neutralityas-political-opinion case, the victim must have had a political motive for choosing neutrality, and his tormentor must have persecuted him for political reasons. Under these requirements, Hecky Brown would apparently be denied asylum. Although his persecutors, HUAC, are unquestionably politically motivated, he is not-he marched in the May Day parade to impress a woman, not to make a political statement.

\section{E. Hecky's Savior-The Imputed Political Opinion Exception}

If Hecky had actually attended the march to show his support for democratic socialism, but HUAC had interpreted his actions as support for Soviet-style Communism, we would surely say that Hecky was persecuted because of his political opinions. The same applies to the politically motivated neutral. There is no principled reason for treating one who chooses neutrality and is persecuted for that neutrality differently from one who chooses neutrality and is persecuted because others incorrectly interpret that neutrality as a hostile political opinion. It matters little to the victim whether his tormentor has correctly understood his political philosophy. The victim faces persecution because he has taken a political stand that his persecutor will not accept.

Hecky, of course, did not taken a political stand. He was motivated by purely personal, apolitical reasons. Nevertheless, dicta in Elias-Zacarias indicates that the requirement that a victim's neutrality be politically motivated might give way when a persecutor misinterprets neutrality (or any other apolitical behavior) as an unacceptable political opinion. ${ }^{110}$ The Ninth Cir-

$107 \quad 767$ F2d at 1287.

${ }^{108}$ See 112 S Ct at 815-16.

${ }^{109}$ For example, many criminal laws require inquiry into the motivations of the accused.

${ }_{110}$ "Nor is there any indication (even assuming it would suffice) that the guerrillas erroneously believed that Elias-Zacarias' refusal was politically based.” $112 \mathrm{~S} \mathrm{Ct}$ at 816. 
cuit refers to this exception to the political-motivation-of-thevictim requirement as the "imputed political opinion" exception. ${ }^{111}$ This exception corresponds to the third means by which the First Circuit suggested a neutral asylum-seeker could qualify as persecuted on account of political belief: when the neutral can demonstrate that "one or more groups intend to persecute him because each (incorrectly) thinks he holds the political views of the other side." 112

The necessity of this exception becomes clear when one recalls that the Refugee Act's "well-founded fear of persecution on account of" language modifies not only political opinion, but also race, religion, nationality, and membership in a particular social group. ${ }^{113}$ As G. Joseph Rees, then-General Counsel of the INS, noted, an excessively strict interpretation of the Elias-Zacarias motivation requirement might deny asylum relief to "a $\mathrm{Mr}$. Rosenberg whom the Nazi government of Germany had sentenced to the gas chamber because it erroneously believed him to be a Jew ...."114 Technically, one might argue that a person cannot be persecuted because he is a Jew if he is not in fact Jewish. Surely, however, neither Congress nor the Supreme Court meant to sacrifice innocents like Mr. Rosenberg to such a mindless formalism. ${ }^{115}$ Reasonable intuition suggests that $\mathrm{Mr}$. Rosenberg is either covered by the Refugee Act, or should be: "[T]he most straightforward meaning of the words 'persecution ... on account of . . . religion' would appear to encompass a program specifically intended to stamp out Judaism even though implementation of the program should lead to some persecution of non-Jews." 116 In other words, the Refugee Act does not protect religion (or political opinion or any other protected ground) per se. Instead, it protects those who have been victimized by, for example, religious intolerance, regardless of whether these victims actually hold targeted religious beliefs. ${ }^{117}$

11 See Canas-Segovia, 970 F2d at 601-02.

112 Novoa-Umania, 896 F2d at 3.

1138 USC \& 1101(a)(42)(A).

114 G. Joseph Rees, III, Memorandum: Continued Viability of the Doctrine of Imputed Political Opinion, reprinted in 70 Interpreter Releases 498, 501 (Apr 12, 1993).

115 See also Note, Immigration and Naturalization Service v. Elias-Zacarias: Partially Closing the Door on Political Asylum, 52 Md L Rev 478, 495 n 124 (1993).

116 Rees, 70 Interpreter Releases at 501. Note that persecution of Jews might also constitute "persecution on account of race" (ethnicity) under the Refugee Act. See 8 USC $\S 1101(\mathrm{a})(42)$.

117 Or, in Hecky Brown's case, the Refugee Act should protect him from persecution arising from HUAC's intolerance of a dissenting political opinion, whether or not Hecky 
Any contrary language in Elias-Zacarias must be understood in light of the specific facts of that case. The Ninth Circuit had broadly held that persecution by a political entity (an anti-government guerrilla group) necessarily constituted political persecution. ${ }^{118}$ The Court sought to refute this theory by emphasizing that "[t]he ordinary meaning of the phrase 'persecution on account of ... political opinion' ... is persecution on account of the victim's political opinion ...."119 The Court's language need not be understood, however, as barring an apolitical victim from gaining asylum when the persecutor's actions are specifically designed and intended to oppress one of the Refugee Act's protected grounds. As with Mr. Rosenberg in the religion context, a straightforward interpretation of "persecution on account of political opinion" should encompass a program specifically intended to stamp out political dissent, even though it targets some non-dissenters-or neutrals whose neutrality is not politically motivated.

This interpretation does not necessarily conflict with the Court's position in Elias-Zacarias. The Elias-Zacarias Court reasoned that under the Refugee Act, the victim's opinion ordinarily controls. In the imputed political opinion context, the victim's opinion controls as well-only the persecutor determines whether the victim has a political opinion. If the persecutor believes that the neutral victim has a political opinion, we assume the victim actually has one.

The imputed political opinion exception to the requirement of a political motive on the part of the neutral victim will not become the exception that swallows the rule. This exception still requires proof that the persecutors took the complained-of action in order to punish the victim for his presumed political views and not, for example, to fill their ranks.

Accordingly, the non-politically motivated neutral will usually have a more difficult time proving the political motivation of the persecutor than the politically motivated neutral. Generally, persecutors do not provide affidavits setting forth their reasons for persecuting. Instead, persecutors, like everyone else, generally do intend the consequences of their actions. Therefore, if a victim is punished following political behavior, the inference of political

\footnotetext{
actually subscribes to that opinion.

${ }_{118}$ Zacarias $v$ United States INS, 921 F2d 844, 850 (9th Cir 1990). See also Maldonado-Cruz, 883 F2d at 791.

${ }^{119}$ Elias-Zacarias, $112 \mathrm{~S} \mathrm{Ct}$ at 816 (emphasis added in part).
} 
persecution is stronger than if the victim is punished following apolitical behavior.

For example, if a citizen is jailed on trespassing charges for walking across the lawn of the president's mansion, the inference of political persecution is weak. If, however, the same citizen is jailed for trespassing after walking across the lawn with a sign that says "Down With the President," the inference of political persecution grows much stronger.

Of course, the first example may in fact be political persecution, and the second example may merely constitute benign, generally applicable law enforcement. The point is that while we should not require a political motivation on the part of the neutral victim in the imputed political opinion context, the Refugee Act still requires a political motivation on the part of the persecutor. In proving the latter, the neutral who has made a conscious, public and politically motivated choice of neutrality, for example, will ordinarily have an easier burden than the neutral who merely fears combat. Therefore, although Hecky Brown's lack of political motivation may make his imputed political opinion case more difficult to prove, if he can nonetheless prove that he was punished because HUAC thought he was a Communist, it makes no difference that he really was not a Communist.

\section{F. A Final Caveat: Insincerely Imputed Political Opinion}

The foregoing analysis overlooked a different interpretation of Hecky Brown's situation: perhaps HUAC knew that Hecky was not a Communist but sought to punish him nonetheless because he would not "name names." 20 The Ninth Circuit seems to allow asylum petitions under such a scenario of insincerely imputed political opinion. In Lazo-Majano $v$ INS, the Ninth Circuit held that an insincere imputation of political opinion does constitute political persecution. ${ }^{121}$ Although the court found that Lazo-Majano held political opinions for which she faced persecution in the form of rape and kidnap by a sergeant in the El Salvadoran military, ${ }^{122}$ the majority held that "[e]ven if she had

120 The film implies as much. See The Front (cited in note 98).

121 See Lazo-Majano v INS, 813 F2d 1432, 1435 (9th Cir 1987).

122 Specifically, the majority held that, placed in its proper "social context," LazoMajano expressed the political views that men do not have the right to dominate women, that the El Salvadoran military was responsible for many crimes, and that the government was not law abiding. Id.

The dissent, however, lampooned the majority's "discovery" of Lazo-Majano's "political opinions." "Quite simply, the majority has outdone Lewis Carroll in its application 
no political opinion and was innocent of a single reflection on the government of her country, the cynical imputation of political opinion to her is what counts ...."123 Lazo-Majano thus stands for the proposition that persecution for personal reasons becomes persecution for political reasons if the persecutor threatens to insincerely impute a false political opinion to the victim and then punish her for it. ${ }^{124}$

The problem with the insincerely imputed political opinion doctrine is that so much turns on the tormentor's choice of weapon. Under the Ninth Circuit approach, a woman kidnapped and raped by an attacker wielding a knife does not suffer political persecution, but if the attacker instead wields a threat of political slander, she does. This reasoning ignores the fact that a persecutor who threatens to falsely label the victim with a political opinion is not seeking to punish that opinion at all, for he knows the opinion is not real but merely his own contrivance.

The purpose of the imputed political opinion doctrine is to provide refugee relief where the politically motivated persecutor has made a mistake in his attempt to attack dissenting political opinion. The insincerely imputed political opinion doctrine turns this on its head-the persecution is not politically motivated and the imputation is not a mistake. The doctrine should therefore have no place in decisions to grant or deny asylum petitions.

\section{CONCLUSION}

The BIA and the federal courts have struggled for many years over political asylum cases in which an alien claims a fear of persecution that cannot be attributed to traditional political activities. "In such cases, there is no affirmative act on which to hang a decision-no bright line to show exactly why the victim has been targeted." 125

of the term 'political opinion' and in finding that male domination in such a personal relationship constitutes political persecution." Id at 1437 (Poole dissenting).

123 Id at 1435.

124 The majority explained that, when the sergeant manipulatively chose to regard Lazo-Majano as a subversive, "he attribute[d] to her the political opinion of a subversive, and she [was] being persecuted on account of a political opinion." Id at 1436.

One commentator offers another understanding of Lazo-Majano: "While [LazoMajano's] actual persecutor knew that she was not a subversive and therefore cannot be said to have persecuted her for her political beliefs, [she] may have had a well-founded fear that others would persecute her because they believed the sergeant's imputations of subversiveness to her." Comment, 63 Wash L Rev at 412 n 109 (cited in note 90). While this may certainly be true and would show a well-founded fear of persecution by "others," it does not show political persecution by the sergeant.

${ }_{125}$ Case Note, Elias-Zacarias v. INS: Neutrality as a Form of Political Opinion, 18 NC 
While many commentators have criticized the Supreme Court's decision in Elias-Zacarias ${ }^{126}$ there is no particular reason to believe that either the Supreme Court or Congress will reverse the Court's holding. Yet, in coming to terms with the tricky issue of neutrality as political opinion, Elias-Zacarias should be taken as a starting point, not a final pronouncement. A proper reading of the case yields several principles to guide interpretation of the Refugee Act's political opinion provision as it relates to neutrality.

First, the persecutor must persecute for reasons of political intolerance. Since the persecutor generally will not be present at trial, the neutral victim might have some difficulty proving that political considerations motivated his persecutor. Courts should adopt the First Circuit's solution to this problem-that is, the victim should be deemed to have been persecuted for political reasons if he can demonstrate that his persecution is due to (1) his persecutor's hatred of neutrals, or (2) the victim's refusal to conform his ideas to his persecutor's political viewpoint. Second, the alien must ordinarily have had a political motivation for choosing neutrality. Finally, even if the alien's neutrality was not politically motivated, he is entitled to refugee protection if the persecutor sincerely interpreted it as such, under the imputed political opinion exception.

This Comment has suggested an approach to the neutralityas political-opinion issue that is faithful to the purposes of the Refugee Act and to Supreme Court precedent. The approach provides refuge to those of "special humanitarian concern to the United States,"127 while recognizing "that the United States cannot accept an unlimited number of refugees from around the world." 128 The approach will help achieve the goal of providing humanitarian relief to the truly politically persecuted neutral, while assuring that neutrality as political opinion does not become the sinkhole that swallows the rule.

J Intl L \& Comm Reg 457, 465 (1993).

${ }^{226}$ See generally Case Note, 18 NC J Intl L \& Comm Reg 457; Note, 67 Wash L Rev 959 (cited in note 78); Note, 25 Cornell Intl L J 231 (cited in note 81); Comment, Immigration and Naturalization Service v. Elias-Zacarias: A Departure From the Past, 15 Fordham Intl L J 1275 (1991-92).

${ }_{127}$ Refugee Act of 1980, § 101(a), Pub L No 96-212, 94 Stat 102 (1980) (congressional declaration of purpose, included as note to 8 USC $\$ 1521$ ).

${ }^{128}$ Anker and Posner, 19 San Diego L Rev at 11 (cited in note 8). 
